\title{
Risk Management of the Bank Interest Rates under the Background of Interest Rate Marketization
}

\author{
Yunlei Huo ${ }^{1, \text { a }}$ \\ ${ }^{1}$ Jilin Business and Technology College, Changchun, Jinlin, China, 130507 \\ ${ }^{a}$ email
}

Keywords: Interest Rates, Marketization, Commercial Banks, Risk Management

\begin{abstract}
In recent years, interest rate risk management has become a commercial bank management in a common management method that most commonly used in the bank's risk management and control. Given Chinese banking spreads in income increases the proportion of bank profits, increased interest rates marketization reform, interest rate management of the bank's gradual emergence of new problems and challenges. In this paper, the current interest rate marketization background, our interest rate risk management in banks is analyzed, and the relevant countermeasures and suggestions in accordance with the bank interest rate risk management.
\end{abstract}

\section{Introduction}

Since the bank interest rates marketization, the focus has been placed on the bank's deposit and lending rates to control, according to the floor on lending rates and deposit interest rate ceiling set floating range. In view of the bank's main income is still spreads, the main business is still a deposit, loans, interest rate marketization reform has a direct impact on our banks. Key of bank interest rates marketization reform is reform of deposit and lending rates, Figure 1.1 is the openness of the bank interest rates:

\begin{tabular}{|l|}
\hline Rate completely open \\
\hline Interest rate between \\
banks \\
Bond market interest \\
rates \\
Spot bond trading and \\
bond interest rates \\
Discount rate \\
Rediscount rate \\
Insurance companies \\
and other large deposit \\
interest rate agreement \\
\hline
\end{tabular}
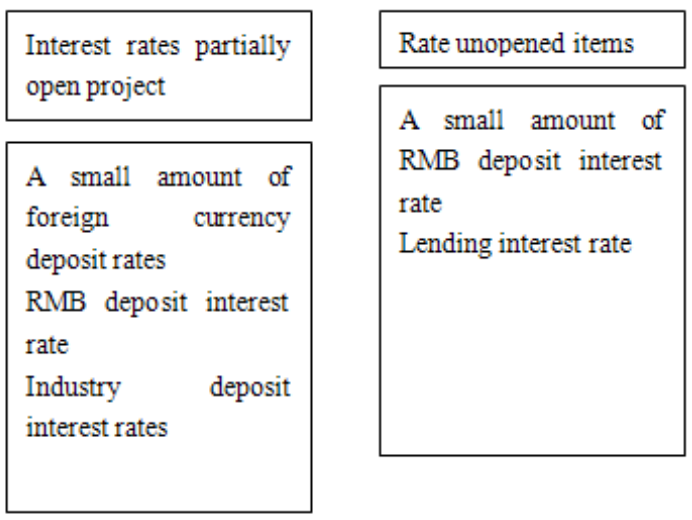

Fig. 1.1 Openness of Bank Rate

\section{The Status of the Bank Interest Rate Risk under Marketization Background}

In China, the bank management structure has become a chronic illness. Deposit structure, a large proportion of high-cost deposits, some banks lack of independent decision-making power, so low allocation efficiency of bank credit funds. Of assets and liabilities, the amount and duration mismatch emerged. Larger deposits than loans increased, and the long-term trend showing deposits, loans and short-term loans mainly places. So our banks face greater risk.

In China, the Treasury bill rate is higher than bank deposit rates, with some spreads. Therefore, banks generally will replace the national debt business loans, so banks to take less risk and still have certain benefits. But in the interest rate marketization background, with the market interest rates increase, investment returns for government bonds weakened, so that our banks face the risk of the yield curve. 
As in recent years, the central bank benchmark interest rate frequent adjustments, and different ranges, such as in 2007 raised interest rates six times a year, in June 2012 in a month twice cut interest rates. Adjustment aspect is as many as $0.31 \%$ lower by $0.18 \%$. Changes in interest rates, deposit and lending rates for the country to the main banks have been affected. Plus, deposit and lending rates to adjust the increase in the number of banks has led to the spread of the frequent fluctuations, and has a margin of uncertainty, leading to increased risk of bank reference.

In China, bank deposits and are in accordance with the customer's own wishes, even deposits also can be extracted in advance, the loan is also possible early repayment in accordance with customer wishes. At present, in view of the interest rate marketization background, the benchmark deposit and lending interest rate adjusted frequently, customers on balance, that the dump income greater than the penalty for early withdrawal, they will choose Move; Similarly, if a customer can be considered in the interest of early repayment require early repayment, the bank may also apply in accordance with the wishes of customers. This way the bank is in a passive position, Moreover, most of the bank deposits are short-term loan and hence the risk of the customer's choice is another big risk in the current interest rate of Bank of marketization background.

\section{Interest Rate Risk Management Strategies under Interest Rate Marketization}

In a certain extent, interest rate marketization promoted the development of financial markets, only has a sound financial market system in order to provide a greater variety of financial instruments, interest rate risk aversion control. At present, Chinese financial market is not perfect, market operations and financial system to be strengthened, I believe that the following two aspects:

With the development of market economy, Chinese money market has been gradually opening up, it has basically realized marketization mechanism to promote the development of financial markets. The gradual improvement of money market can be effective in attracting people's participation, increase market transactions varieties and improve the efficiency of the money market.

The gradual improvement of the stock market in favor of banks balance adjustment, the bank can use the securities business to hedge interest rate risk. Development of financial derivative products can provide a wider range of operating space for banks to effectively hedge interest rate risk.

After the interest rate marketization, financial regulation is more important, the bank's risk management need independent oversight bodies. Independent monitoring should be based on a sound regulatory system, from government intervention, targeted and accurate risk management and business banking will be monitored. In our banking system should be diversified financial regulatory mechanisms, administrative, economic and legal supervision and mutual cooperation. First, we should focus on the transition from the traditional legal and administrative regulation to economic regulation, and constantly improve the relevant laws and regulations of financial supervision. Second, the means to enhance the current financial regulation are important. Achieve diversification of financial regulation at the same time, to take full advantage of the current high-tech technology, the financial activities of information science and technology supervision.

In China, the Bank mainly through the rational allocation of assets and liabilities for asset and liability management, the Bank is one of the ways to avoid the interest rate risk. With the interest rate risk management processes and continuous progress, asset-liability management Rate marketization bank also showed its importance, in view of Chinese banking assets and liabilities management started late, incomplete development, the key is to adjust the ratio of assets and liabilities to assets liability management.

Given the current risk profile of the bank, the following two aspects should be managed within the bank's assets and liabilities: First, banks should attract and select excellent source to improve the bank's profitability and improving asset quality, while bank liabilities strengthen cost consciousness, development and stability of the deposit item, increase the proportion of time deposits. Second, actively promote the basic model of bank assets and liabilities management, improve asset-liability management standards and effective monitoring to prevent the balance expansion to accelerate and intensify to reduce interest rate risk. 
With interest rates marketization, the banking industry to achieve the independent pricing of financial products, but the price will need to do a suitable and effective pricing mechanism, so as to improve operational efficiency and control interest rate risk. The current pricing of financial products has basically achieved the data, some banks the Bank developed the appropriate software pricing, basically solved the technical problem of pricing. But to do product pricing also need an effective pricing mechanism. In China, all banks are essentially modeled on overseas pricing model, suitable for China to establish a hierarchical authorization pricing mechanism. Mainly through the establishment of internal quotation system headquarters, each branch under the authority of the head office and the market competition, the current financial products in a reasonable price based on local economic conditions. Given the differences in local market competition and economic development of the bank can develop its own pricing strategy.

In China, the lack of interest rate risk management of personnel and training of qualified personnel is imminent interest rate risk management. Our banks should actively to various channels and means to interest rate risk management focus on training personnel, and enhance the awareness of personnel management, training mode can be taken step by step through multiple channels, develop a team with interest rate risk management practices, the use of high technology and flexible interest rate risk management personnel. Meanwhile, Chinese banks should attach importance to training innovative talents, to be able to develop appropriate bank interest rate management practices in accordance with the current situation of Chinese national conditions and the actual situation of the bank.

\section{References}

[1] Hua Yaqin. Bank interest rate risk management analysis[J]. Financial Times, 2010, 5

[2] Gao Fang. Rate Marketization reform process in the interest rate risk management of Bank study [D]. Jinan University, 2012

[3] Tan Huimin. Interest Rate Marketization Process of Interest Rate Risk Management of Bank study [D]. Yunnan University of Finance and Economics 2011

[4] Wolfgang Bauer, Marc Ryser. Risk management strategies for banks[J]. Journal of Banking and Finance, 2004

[5] Bhaumik, S.K. and Majumdar, S. The impact of monetary policy on corporate borrowing in India: an empirical investigation [J]. Money and Finance, 2007, (09): 69-88. 